\title{
High-performance cellulosic filament fibers prepared via dry-jet wet spinning from ionic liquids
}

\author{
Marc P. Vocht • Ronald Beyer • Patricija Thomasic $\cdot$ Alexandra Müller • \\ Antje Ota $\cdot$ Frank Hermanutz $\cdot$ Michael R. Buchmeiser $(\mathbb{D}$
}

Received: 18 November 2020/Accepted: 13 January 2021 / Published online: 1 February 2021

(C) The Author(s) 2021

\begin{abstract}
We report on a new process for the spinning of high-performance cellulosic fibers. For the first time, cellulose has been dissolved in the ionic liquid (IL) 1-ethyl-3-methylimidazolium octanoate ([C2C1im][Oc]) via a thin film evaporator in a continuous process. Compared to other ILs, [C2C1im][Oc] shows no signs of hydrolysis with water. For dope preparation the degree of polymerization of the pulp was adjusted by electron beam irradiation and determined by viscosimetry. In addition, the quality of the pulp was evaluated by means of alkali resistance. Endless filament fibers have been spun using dry-jet wet spinning and an extruder instead of a spinning pump, which significantly increases productivity. By this approach, more than
\end{abstract}

Supplementary information The online version contains supplementary material available at https://doi.org/10.1007/ s10570-021-03697-x.

M. P. Vocht - R. Beyer - P. Thomasic .

A. Müller · A. Ota $\cdot$ F. Hermanutz $(\bowtie)$.

M. R. Buchmeiser ( $\square)$

German Institutes of Textile and Fiber Research

Denkendorf (DITF), Körschtalstr. 26, 73770 Denkendorf,

Germany

e-mail: frank.hermanutz@ditf.de

M. R. Buchmeiser

e-mail: michael.buchmeiser@ditf.de

M. R. Buchmeiser

Institute of Polymer Chemistry, University of Stuttgart,

Pfaffenwaldring 55, 70569 Stuttgart, Germany
$1000 \mathrm{~m}$ of continuous multifilament fibers have been spun. The novel approach allows for preparing cellulose fibers with high Young's modulus (33 GPa) and unprecedented high tensile strengths up to $45 \mathrm{cN} /$ tex. The high performance of the obtained fibers provides a promising outlook for their application as replacement material for rayon-based tire cord fibers.

Keywords Cellulose $\cdot$ Ionic liquid $\cdot$ Man-made cellulose fibers · Dry-jet wet spinning · Tire cord

\section{Introduction}

Cellulose is the second most important raw material used in fiber industry (The Fibre Year 2019: World Survey on Textiles and Nonwovens 2019). Currently, cotton has the largest market share of cellulose based fibers; however, with the lowest expected growth rate. Thus, the global textile fiber production is expected to increase to 133.5 million tons per year until 2030 while cotton production is expected to tableau around annual 26-28 million tons (Haemmerle 2011). The resulting, so called "cellulose gap" has to be closed. Current strategies include an increased use of wood cellulose, identification of additional cellulosic sources, e.g. biomass, but also fabric reuse, and recycling (El Seoud et al. 2020). The use of wood pulp for fiber production can be traced back for a long 
time (Bredereck and Hermanutz 2005). Currently, there are only two technologies that have been industrialized for man-made cellulosic fiber (MMCF) production. Although being the oldest commercially utilized method, the viscose process still dominates the fabrication of regenerated cellulosic fibers (Shearer 1925). Wood pulp has to be pretreated using sodium hydroxide forming alkali cellulose (Cook 1968). This chemical aging leads to a degradation of the cellulose and is important for the final processing of the viscose solution. The longer the ageing time, the lower the viscosity of the solution is. The aged alkali cellulose is then mixed with carbon disulfide $\left(\mathrm{CS}_{2}\right)$ to form cellulose xanthate, which is dissolved in diluted sodium hydroxide solution. This solution is spun into a coagulation bath containing sulfuric acid and salts like sodium and zinc sulphate. During coagulation, the cellulose xanthate is transformed back into cellulose. Apart from high water consumption up to $850 \mathrm{~L} / \mathrm{kg}$, the main issue of the viscose process is the use of highly toxic and ecologically harmful chemicals, which reduces the incentive of this methodology (Bredereck and Hermanutz 2005; Sayyed et al. 2019; Vigliani 1954). Federally regulated extensive waste treatment has become the cost-determining factor and is necessary to ensure that neither highly toxic and ecologically harmful $\mathrm{CS}_{2}$, hydrogen sulfide nor heavy metal compounds formed during precipitation are released into the environment. However, the flexibility of the process is a major advantage that should not be ignored. Viscose fibers can not only be used as textile fibers but also in many different ways, e.g. in the form of fibers with special fiber geometry ("Y" shaped fibers with improved water imbibition) or high tenacity fibers (Polysonic) (Wooding 1995). Beside fiber spinning, the metastable soluble cellulose xanthogenate can be used for the production of films (cellophane) and other materials (Fink et al. 2001). The second major process for producing cellulosic fibers is the Lyocell process. In contrast to the viscose process, no derivatization of the cellulose is necessary (Loubinoux and Chaunis 1987). Instead, a cyclic amine oxide, i.e. $\mathrm{N}$-methylmorpholine $\mathrm{N}$-oxide (NMMO) is used as a direct solvent. Compared to the viscose process, the Lyocell process is much more environmentally friendly and efficient (Bredereck and Hermanutz 2005). Apart from the environmental advantage, Lyocell fibers are also of high quality with excellent mechanical properties making them suitable for many applications (Schuster et al. 2004). However, the cellulose/NMMO solution suffer from side reactions and by-product formation affecting the fiber properties. Therefore, the spinning dope needs to be stabilized by the addition of isopropyl gallate to suppress these side reactions (Rosenau et al. 2002; Zhang et al. 2018).

Due to the disadvantages of the established processes, recent efforts focused on new technologies for MMCF production (Hermanutz et al. 2020). Within this context, the use of $N, N$-dimethylacetamide (DMAc) in combination with $\mathrm{LiCl}$ as a possible solvent medium was considered, as it allows for high cellulose concentrations of up to $16 \mathrm{wt} . \%$ and recovery of the solvent (Sayyed et al. 2019). However, this solvent system requires an "activation step" to dissolve cellulose, which renders it expensive and corrosive. Alternative spinning systems are based on water (Mittal et al. 2018, 2019; Vehviläinen et al. 2015; Yamane et al. 1996). The group of Söderberg used the hydrodynamic alignment of cellulose nanofibrils (CNFs) suspended in water (Mittal et al. 2018, 2019). With this flow-assisted self-organization of the fibrils, macroscale fibers with Young's moduli of up to $86 \mathrm{GPa}$ and tensile strengths of $1.57 \mathrm{GPa}$ were obtained. Nonetheless, the development of such CNFbased fibers is still in its early stages and it remains to be seen how far the process can be improved in terms of productivity, i.e. process speed and use of multihole spinnerets. Among many approaches, ionic liquid (IL) technology is amongst the most promising (El Seoud et al. 2020; Hermanutz et al. 2020; Isik et al. 2014; Sayyed et al. 2019; Sun et al. 2011; Wang et al. 2012; Zhang et al. 2017a). Like NMMO and DMAc/ $\mathrm{LiCl}$, ILs are direct solvents for cellulose. Selected ILs show good dissolution capacity for cellulose allowing for cellulose concentrations of up to $39 \mathrm{wt} \%$ (Hermanutz et al. 2020). One benefit of this technology is that ILs dissolve cellulose under rather mild conditions without the use of additives (Swatloski et al. 2002). Beside that, other physical, chemical, and biological properties like low melting point, low flammability, low chemical reactivity, high thermal stability and low toxicity make this class of solvents highly attractive (Hough et al. 2007; Ostadjoo et al. 2018). For industrial use, any selected IL has to match specific economic and ecological criteria like recyclability $(>99.5 \%)$, low propensity for side reactions, lowest possible toxicity, and excellent cellulose 
dissolution capability, in order to create a sustainable processes (Hermanutz et al. 2020; Ostadjoo et al. 2018). A recent review summarizes all relevant cellulose dissolution and spinning processes together with relevant developments towards industrialization of the IL-technology (Hermanutz et al. 2018). So far, most spinning processes are based on imidazoliumbased ILs. Notably, some imidazolium-based ILs are unsuitable for industrialization despite their good solubility for cellulose and good fiber properties with tensile strengths up to $808 \mathrm{MPa}$ and Young's moduli up to $30 \mathrm{GPa}$ of the resulting fibers (Jiang et al. 2012; Kosan et al. 2007, 2012; Zhang et al. 2017b, 2019, 2020). This is not only due to their corrosive behavior, but also to the toxicity of these ILs, as is the case with 1-butyl-3-methylimidazolium chloride $\left(\left[\mathrm{C}_{4} \mathrm{C}_{1} \mathrm{im}\right][\mathrm{Cl}]\right)$ (Couling et al. 2006). However, imidazolium-based ILs with short alkyl side chains and harmless anions like 1-ethyl-3-methylimidazolium acetate $\left(\left[\mathrm{C}_{2} \mathrm{C}_{1} \mathrm{im}\right][\mathrm{OAc}]\right)$ are less toxic (Ostadjoo et al. 2018; Ruokonen et al. 2016). Furthermore, imidazolium-based ILs are not inert. It has been shown that cellulose dissolved in, e.g. chloride-containing ILs, degrade over time and with increasing temperature (Ebner et al. 2008; King et al. 2012). It was also shown that cellulose reacts with carboxylate-based ILs in two ways. On the one hand, the imidazolium cation can react with the cellulose forming new cationic species (Clough et al. 2015; Ebner et al. 2008). On the other hand, cellulose degrades over time in carboxylate-based ILs such as $\left[\mathrm{C}_{2} \mathrm{C}_{1} \mathrm{im}\right][\mathrm{OAc}]$ or 1-ethyl-3-methylimidazolium octanoate $\left(\left[\mathrm{C}_{2} \mathrm{C}_{1} \mathrm{im}\right][\mathrm{Oc}]\right)$, especially at higher temperatures $\left(>90{ }^{\circ} \mathrm{C}\right)$ (Ebner et al. 2008; Ingildeev et al. 2013; Michud et al. 2015a; Olsson et al. 2014). Although the rate of the degradation and side reactions can be reduced by lowering the operating temperature, their formation cannot entirely be prevented.

Beside imidazolium-based ILs there are other ILs able that are capable of dissolving cellulose (Hermanutz et al. 2020). One of the most studied systems is the protic IL diazabicyclo[4.3.0]non-5-enium acetate ([DHBN][OAc]), (Asaadi et al. 2018, 2016; Guizani et al. 2020; Haslinger et al. 2019a, b, c; Hauru et al. 2014; Hummel et al. 2015; Ma et al. 2016; Michud et al. 2015b, c, 2016; Parviainen et al. 2013; Sixta et al. 2015; Wanasekara et al. 2016) which is used in the IONCELL-F process. Fundamental research addressed the influence of the molecular weight distribution of the cellulose, process parameters like draw ratio, coagulation bath temperature, air gap length and the air gap conditioning on the properties of the final fibers (Guizani et al. 2020; Michud et al. 2015b, 2016). Alternative approaches to closing the cellulose cycle entail the use of textile or cotton waste or of cardboard (Asaadi et al. 2016; Haslinger et al. 2019a, b; Ma et al. 2016). It seems to be an advantage that this type of IL can be distilled, which could simplify the recycling of the solvent (Osmanbegovic et al. 2020; Parviainen et al. 2015). However, despite this potential advantage, decomposition of [DHBN][OAc] during distillation reportedly results in an imbalance between the anion and cation (Ahmad et al. 2016). Furthermore, the IL undergoes hydrolysis with water, which further complicates the recycling concept (Ostonen et al. 2016; Parviainen et al. 2015). Nonetheless, there exist various approaches to solve this challenge for both [DHBN][OAc] and imidazolebased ILs (Elsayed et al. 2020; King et al. 2012).

While most publications describe the production of staple fibers suitable for use in the textile industry, the use of cellulosic fibers is by far not limited to these applications, the mores since special viscose fibers are used as tire cord fibers and as reinforcement fibers for composites (Schneck et al. 2019; Spörl et al. 2017a; Wooding 1995; Zadorecki et al. 1986). In this study we present an IL-based spinning process that allows for the production of endless multi-filament fibers with properties comparable to those of commercial tire cord fibers. The imidazolium-based IL $\left[\mathrm{C}_{2} \mathrm{C}_{1} \mathrm{im}\right][\mathrm{Oc}]$ was used as solvent for cellulose since it can be recycled with high purity (Lang et al. 2013). Also, the water used for coagulation and washing can be reused and closed process cycles can be established.

\section{Experimental}

Materials

Eucalyptus sulfite pulp (Sappi) with a DP of 930 was used for fiber spinning. 1-Ethyl-3-methylimidazolium octanoate $\left(\left[\mathrm{C}_{2} \mathrm{C}_{1} \mathrm{im}\right][\mathrm{Oc}]\right)$ was supplied in technical grade by BASF $\mathrm{SE}$. 
Determination of pulp purity by R-18

The alkali resistance based on the determination of the residue R18 was measured according to DIN 54,355.

Degradation of the pulp

For degradation, the pulp was subjected to electron beam (EB) irradiation to reduce the degree of polymerization $(D P)$ in a controlled manner. EB irradiation was carried out with an EC-LAB 400 electron beam device from Electron Crosslinking AB. All pulp plates were irradiated on both sides applying $40 \mathrm{kGy}$ and an acceleration voltage of $180 \mathrm{keV}$.

Viscometric determination of $D P$

The DP of the cellulose was measured according to DIN 54270 using a Schott Geräte GmbH Ubbelohde viscosimeter (Type Ia) in an alkaline solution of the $\mathrm{Fe}$ (III) tartaric acid-sodium-complex (FeTNa). The FeTNa solution was prepared by dissolving $217.2 \mathrm{~g}$ sodium tartrate $2 \mathrm{H}_{2} \mathrm{O}$ in $300 \mathrm{~mL}$ deionized water and dissolving $81.2 \mathrm{~g} \mathrm{FeCl}_{3} \cdot 6 \mathrm{H}_{2} \mathrm{O}$ in $250 \mathrm{~mL}$ deionized water. Both solutions were moderately heated and combined under stirring within $15 \mathrm{~min}$. The mixture was cooled to $15{ }^{\circ} \mathrm{C}$ and a solution of $96.0 \mathrm{~g} \mathrm{NaOH}$ in $180 \mathrm{~mL}$ deionized water was added dropwise. The resulting green solution was diluted with deionized water to $1 \mathrm{~L}$ total volume and stored at $5{ }^{\circ} \mathrm{C}$. 40 $50 \mathrm{mg}$ cellulose powder were weighed in volumetric flasks and filled with $30 \mathrm{~mL}$ FeTNa solution and stirred over night at $0{ }^{\circ} \mathrm{C}$. After tempering the solutions to $20^{\circ} \mathrm{C}$, the volumetric flasks were filled up with another $20 \mathrm{~mL}$ FeTNa. The cellulose solutions were filled into the capillary viscosimeter. Elution times (t) were measured at $20{ }^{\circ} \mathrm{C}$ and compared to those of the pure FeTNa solution $\left(\mathrm{t}_{0}\right)$. Two solutions per cellulose sample were prepared. The $D P$ was calculated according to the Mark-Houwink equation:

$[\eta]=K \cdot\left(M_{M} \cdot D P\right)^{a}$

with the molecular weight of the monomer $M_{M}=162 \mathrm{~g} / \mathrm{mol}, \mathrm{a}=1$ and $K \cdot M_{M}=152$ (Archwal et al. 1967).
Dissolution of cellulose in $\left[\mathrm{C}_{2} \mathrm{C}_{1} \mathrm{im}\right][\mathrm{Oc}]$

For all spinning trials, dopes containing $12 \mathrm{wt} . \%$ of cellulose were prepared. First, the pulp and $\left[\mathrm{C}_{2} \mathrm{C}_{1 \text { - }}\right.$ im][Oc] were mixed for $30 \mathrm{~min}$ at room temperature in a kneader. The obtained slurry was conveyed through a spiral pump at a rotational frequency of $100 \mathrm{~Hz}$ and degassed at $120^{\circ} \mathrm{C}$ and 60 mbar in a thinfilm evaporator (VTA GmbH \& Co. KG). The dope was filled into a pressure filtration cauldron from KarlKurt Juchheim Laborgeräte GmbH with the aid of a heated $\left(110^{\circ} \mathrm{C}\right)$ gear pump, Fig. S1 (S.I.).

Rheology of the spinning dopes

Rheological measurements were performed on an Anton Paar MCR 301 rheometer equipped with a Peltier temperature-control system and parallel-plate geometry. The plate diameter was $25 \mathrm{~mm}$; the gap was $1 \mathrm{~mm}$. Dynamic oscillatory experiments were accomplished with shear rates between 0.1 and $100 \mathrm{~s}^{-1}$ and a deformation of $10 \%$ at temperatures between 110 and $20^{\circ} \mathrm{C}$. Storage and loss modulus $\left(G^{\prime}\right.$ and $\left.G^{\prime \prime}\right)$ and the complex viscosity $\left(\eta^{*}\right)$ were determined. With the principle of frequency-temperature superposition, master curves were obtained. The zero-shear viscosity $\eta_{0}$ was calculated by the Carreau-Gahleitner model (Gahleitner and Sobczak 1989).

\section{Air gap spinning}

Multi-filament fiber spinning was performed on a laboratory-scale device (Fig. 2, S.I.) at $55^{\circ} \mathrm{C}$ and $65{ }^{\circ} \mathrm{C}$. The spinning dope was passed through a filter with a mesh size of $0.043 \mathrm{~mm}$. The extruder was heated and propelled the spinning dope through a multi-hole spinneret (250 capillaries, $450 \mu \mathrm{m}$ capillary length, $150 \mu \mathrm{m}$ capillary diameter) into a 1-m coagulation bath containing water at $18{ }^{\circ} \mathrm{C}$ via an air gap $(10 \mathrm{~mm})$ at an injection speed of $1.5 \mathrm{~m} / \mathrm{min}$. Filaments were wound on godets at velocities between 8.5 and $17.0 \mathrm{~m} / \mathrm{min}$ before running through two washing baths, each one meter in length, and two washing godets. Before being wound onto a bobbin, the fibers were tempered $\left(80^{\circ} \mathrm{C}\right)$ on a heated godet. 
Morphology

Scanning electron micrograph (SEM) pictures were recorded on a Zeiss Auriga field emission scanning electron microscope. Samples were sputtered with Pt/ Pd before analysis.

\section{Fiber orientation}

The average total orientation of the cellulosic fibers was determined by birefringence $(\Delta n)$ measurements using a Leitz Laborlux 12POL polarization microscope $(\lambda=546 \mathrm{~nm})$ equipped with a Leitz compensator B. Fiber samples were cut wedge-shaped and wetted with paraffin oil. $\Delta n$ was obtained by dividing the measured retardation of the polarized light $(\Gamma)$ by the respective fiber diameter (d).

The total orientation $\left(f_{\mathrm{t}}\right)$ was obtained by dividing $\Delta n$ by the maximum birefringence of cellulose $\left(\Delta n_{\max }=0.062\right)$ (Lenz et al. 1992). It was assumed that the maximum birefringence values of the amorphous and crystalline phase are identical, i.e. $\Delta n_{\mathrm{cr}}(-$ $\max )=\Delta n_{\mathrm{am}}(\max )=0.062($ Lenz et al. 1992, 1993).

$\Delta \mathrm{n}=\frac{\Gamma}{\mathrm{d}}$

$\mathrm{f}_{\mathrm{t}}=\frac{\Delta \mathrm{n}}{\Delta \mathrm{n}_{\max }}$

\section{Wide-angle $X$-ray scattering}

For wide-angle X-ray scattering (WAXS), a Rigaku D/ Max Rapid II operated at $40 \mathrm{kV}$ and $30 \mathrm{~mA}$ with $\mathrm{Cu}$ $\mathrm{K} \alpha$ radiation $(\lambda=1.54059 \AA)$ was used. A shine monochromator and an image plate detector were employed. The scanning rate was $0.2^{\circ} / \mathrm{min}$ with $0.1^{\circ}$ scanning steps. All fibers were aligned in a fiber sample holder. The degree of crystallinity was calculated according to the peak deconvolution method using pseudo-Voigt functions for curve fitting via PDXL software (Rongpipi et al. 2018) using

$I_{c}=\frac{\sum I_{c}}{\sum\left(I_{c}+I_{a}\right)}$,

where $I_{\mathrm{c}}$ and $I_{\mathrm{a}}$ are the integrated intensities of the crystalline and the amorphous reflections, respectively. The crystallite size $(t)$ was calculated according to Scherrer's equation (Scherrer 1918).
$\mathrm{t}=\frac{\mathrm{K} \lambda}{\mathrm{B} \cdot \cos \theta_{\mathrm{b}}}$, with the width at half-height of the reflection $(B)$, the wavelength $(\lambda)$, the Scherrer factor $(K)$, which depends on the crystallite shape, and the Bragg-angle $\left(\theta_{\mathrm{b}}\right)$.

\section{Mechanical properties}

The fineness (dtex), tensile strength (cN/tex), elongation at break (\%) and Young's modulus (cN/tex) were measured using a Favimat from Textechno according to EN ISO $5079(20 \mathrm{~mm}$ gauge length, $10 \mathrm{~mm} / \mathrm{min}$ test speed). Fiber samples were conditioned prior to the measurement $\left(20{ }^{\circ} \mathrm{C}, 60 \%\right.$ humidity) and tested. All fiber properties listed are calculated on the basis of 20 individual measurements.

\section{Results and discussion}

Analysis and degradation of the cellulose

For the production of the spinning solution, cellulose with a DP between 400 and 800 has been reported to be particularly suitable (Abels et al. 2017). Therefore, pulp degradation by EB irradiation was performed before the production of the spinning solution. This degradation process is based on the splitting of the cellulose chains by the EB (Seo et al. 2013). The effect of EB radiation on cellulose has been evaluated in several studies (Emsley and Stevens 1994; Hwang et al. 2020; Imamura et al. 1972; Nakamura et al. 1985). In particular, the relationship between the number of chain scissions and the EB dose was described (Bouchard et al. 2006; McLaren 1978). However, degradation of cellulose with increasing EB dose appears to proceed in a nonlinear manner. Henninges et al. and $\mathrm{Ma}$ et al. outlined that EB treatment favors the degradation of high-molar-mass cellulose chains (Henniges et al. 2012; Ma et al. 2016). They showed that this results in a narrower molecular weight distribution. Degradation of cellulose via EB treatment also comprises oxidative degradation, thereby forming carbonyl and carboxyl groups (Imamura et al. 1972; Nakamura et al. 1985). Besides, EB treatment was also reported to reduce crystallinity and increase the available surface area (Driscoll et al. 2009). A lower crystallinity of the cellulose can facilitate the dissolution process of cellulose by 
Table $1 D P, \mathrm{R} 18$ value, water and ash content of the cellulose pulp before and after EB irradiation

\begin{tabular}{llllll}
\hline & $\mathrm{DP}_{\mathrm{FeTNa}}$ & $\mathrm{EB}$ dose $(\mathrm{kGy})$ & $\mathrm{R} 18(\%)$ & Water content $(\%)$ & Ash content $(\%)$ \\
\hline Before EB & 990 & 0 & 93 & 4.3 & 0.1 \\
After EB & 605 & 80 & 92 & 4.1 & 0.1 \\
\hline
\end{tabular}
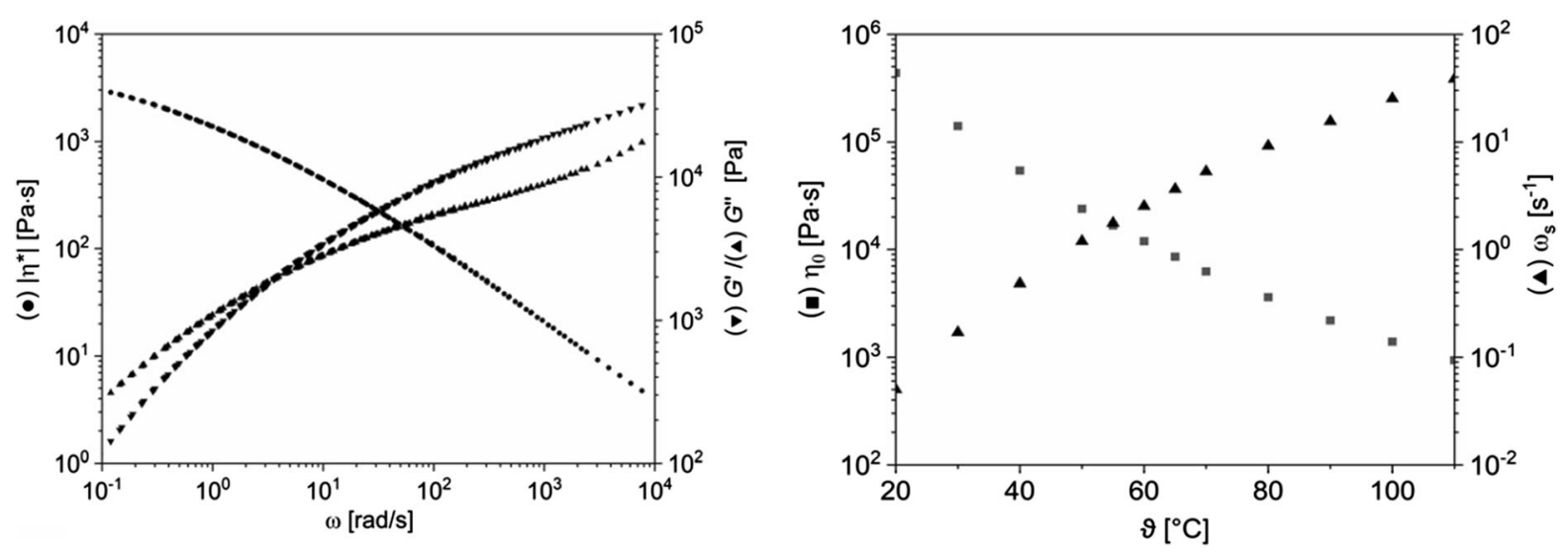

Fig. 1 Rheological behavior of the spinning dope (12 wt.\% cellulose in $\left.\left[\mathrm{C}_{2} \mathrm{C}_{1} \mathrm{im}\right][\mathrm{Oc}]\right)$ left: master curve at reference temperature $65^{\circ} \mathrm{C}, \operatorname{I\eta } * \mid(\mathbf{O}), G^{\prime}(\boldsymbol{\nabla}), G^{\prime \prime}(\boldsymbol{\Delta})$; right: rheological parameters $\eta_{0}(\boldsymbol{\square})$ and $\omega_{\mathrm{S}}(\boldsymbol{\Delta})$ in dependence of temperature

enhancing penetration with solvent. Overall, EB treatment has some advantages over chemical hydrolysis. It is a time- and energy-efficient as well as chemical-saving method for the reduction of the DP of cellulosic materials (Henniges et al. 2013; Stepanik et al. 2000). While DP reduction via alkali treatment takes place in several steps and is difficult to control, EB treatment is a single step, easy to control and highly reproducible. Also, since the cellulose should be as dry as possible for processing with ILs, any chemical pretreatment is disadvantageous. The starting pulp had an average DP of 990, which was reduced to a DP of 605 by applying a dose of $80 \mathrm{kGy}$, Table 1 . Besides the DP, the alkali resistance ( $\mathrm{R} 18$ value) was also tested using a $18 \mathrm{wt}$.\% $\mathrm{NaOH}$ solution. The R18 value describes the amount of the cellulose material, which is not dissolved in this $\mathrm{NaOH}$ solution. This value is commonly used to describe the quality of pulp used for cellulosic fiber spinning (Fechter et al. 2020). The determined $\mathrm{R} 18$ values of the cellulose before and after the degradation were similar indicating no significant changes in the quality of the pulp.
Characterization of the spinning dope

Rheology measurements of the cellulose/IL dopes are a well-established method to determine the spinnability of a solution (Ingildeev et al. 2013; Olsson and Westman 2013). Since the polymer-solvent interactions are directly related to the viscosity one can also determine the storage and loss modulus $\left(G^{\prime}\right.$ and $\left.G^{\prime \prime}\right)$. The relationship between both moduli can provide more information about polymer-polymer interactions (Spörl et al. 2017b). For viscoelastic materials a crossover point $\left(G^{\prime}=G^{\prime \prime}\right)$ is expected at some frequency $\left(\omega_{\mathrm{S}}\right)$. For $G^{\prime \prime}>G^{\prime}$, the system is considered to be a fluid, in the opposite case the system is gel-like. However, rheology measurements with a conventional rheometer using a plate-plate system can only give an indication for the spinning conditions as the conditions in the spinneret cannot be simulated.

A spinning solution consisting of $12 \mathrm{wt} . \%$ cellulose in $\left.\left[\mathrm{C}_{2} \mathrm{C}_{1} \mathrm{im}\right][\mathrm{Oc}]\right)$ displayed a non-Newtonian viscous behavior, which resulted in the shear-thinning of the viscoelastic fluid, Fig. 1. As expected, lower temperatures resulted in higher viscosities, Fig. S2 (S.I.). 
Table 2 Air gap spinning conditions of 12 wt. $\%\left[\mathrm{C}_{2} \mathrm{C}_{1} \mathrm{im}\right][\mathrm{Oc}]$ spinning solution

\begin{tabular}{|c|c|c|c|c|c|c|c|}
\hline \multirow[t]{2}{*}{ Serial } & \multirow[t]{2}{*}{$\begin{array}{l}\text { Temperature } \\
\left({ }^{\circ} \mathrm{C}\right)\end{array}$} & \multirow[t]{2}{*}{$\begin{array}{l}\text { Zero-shear viscosity } \\
(\mathrm{Pa} \mathrm{s})\end{array}$} & \multicolumn{2}{|c|}{$\begin{array}{l}\text { Cross over } \\
\text { point }\end{array}$} & \multirow[t]{2}{*}{$\begin{array}{l}\text { Hole diameter } \\
(\mu \mathrm{m})\end{array}$} & \multirow[t]{2}{*}{$\begin{array}{l}\text { Number of } \\
\text { holes }\end{array}$} & \multirow[t]{2}{*}{$\begin{array}{l}\text { Maximum draw } \\
\text { ratio }\end{array}$} \\
\hline & & & $\left(\mathrm{s}^{-1}\right)$ & $\overline{(\mathrm{Pa})}$ & & & \\
\hline A & 55 & 16,720 & 1.76 & 1835 & 150 & 250 & 11 \\
\hline B & 65 & 8551 & 3.64 & 1940 & 150 & 250 & 10.5 \\
\hline
\end{tabular}
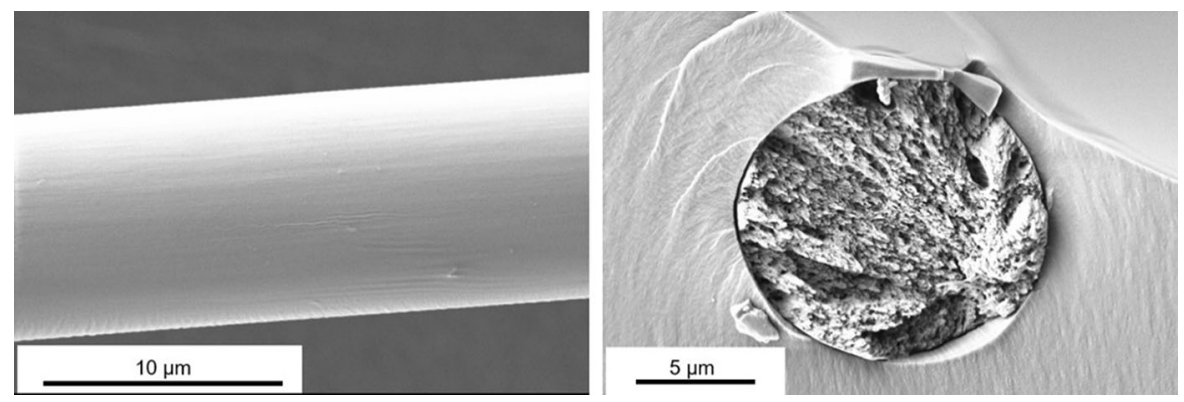

Fig. 2 SEM of a regenerated fiber. Left: fiber surface. Right: cross section

Accordingly, at lower temperatures lower frequencies were necessary to reach the reversible gel point. With increasing temperature $\eta_{0}$ decreased, while $\omega_{\mathrm{S}}$ increased.

\section{Dry-jet wet spinning}

Based on the rheology measurements, two temperatures, i.e. 65 and $55{ }^{\circ} \mathrm{C}$ were chosen for spinning. The multifilament bundles produced were extruded into a coagulation bath (water) after passing an air gap of $10 \mathrm{~mm}$ and continuously washed with water. Fibers were dried on a heated godet roll and then wound on a bobbin, Fig. S5 (S.I.) Table 2 summarizes the parameters for fiber spinning based on the air gap (dry-jet wet) spinning process. Approximately $1000 \mathrm{~m}$ of continuous filament were wound onto each bobbin.

Fiber morphology

A representative SEM picture of a prepared fiber is shown in Fig. 2. Because of the rapid coagulation, all fibers showed a smooth surface with no visible defects. The round cross section of the fibers is a result of the dry-jet wet spinning technique. Furthermore, the fibers showed a fibrillar structure network (Fig. S6, S.I.) due to the preorientation of the molecular chains in the air gap (Ingildeev et al. 2013). The fibers did not show any visible voids or signs of a skin-core structure in the cross-section.

At this point it should be emphasized that the coagulation bath was not changed during the spinning trials. Therefore, the concentration of the IL increased from 0 to approx. 20 wt.\% over the entire spinning process as determined by refractometry measurements (Fig. S7, S.I.). No major changes in the fiber morphology could be observed with increasing IL concentration in the coagulation bath. Those results have direct consequences for the up-scaling of the process. The possibility to operate at a relatively high concentration of the IL in the coagulation bath potentially reduces the energy costs during solvent recovery.

Since the coagulation of cellulose from an IL is a diffusion-based process, the complete removal of the IL from the final fibers requires a certain period of contact time in a coagulation or washing bath (Parviainen et al. 2015; Zhang et al. 2020). Due to the 

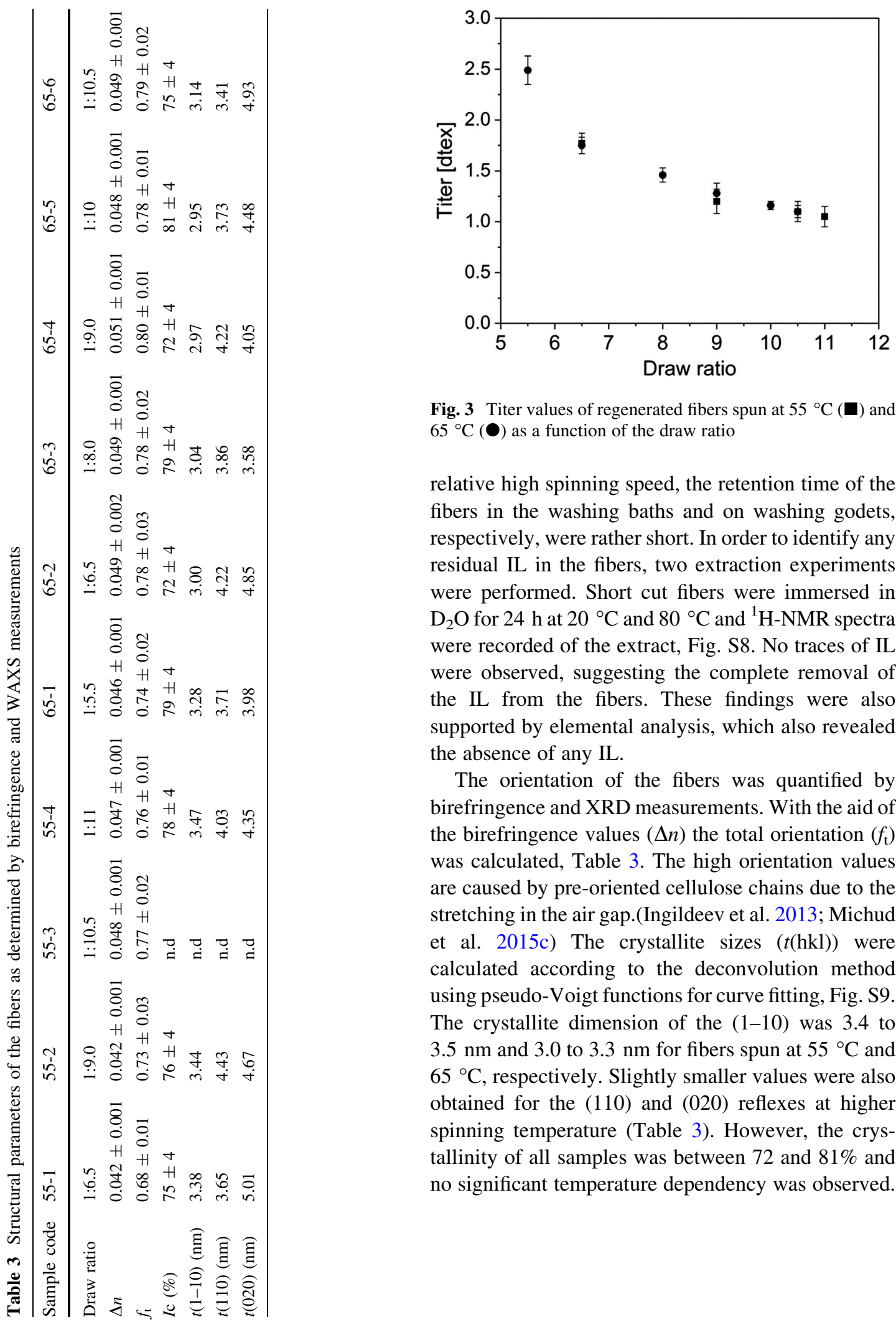

Fig. 3 Titer values of regenerated fibers spun at $55^{\circ} \mathrm{C}(\boldsymbol{\square})$ and $65^{\circ} \mathrm{C}(-)$ as a function of the draw ratio

relative high spinning speed, the retention time of the fibers in the washing baths and on washing godets, respectively, were rather short. In order to identify any residual IL in the fibers, two extraction experiments were performed. Short cut fibers were immersed in $\mathrm{D}_{2} \mathrm{O}$ for $24 \mathrm{~h}$ at $20{ }^{\circ} \mathrm{C}$ and $80{ }^{\circ} \mathrm{C}$ and ${ }^{1} \mathrm{H}-\mathrm{NMR}$ spectra were recorded of the extract, Fig. S8. No traces of IL were observed, suggesting the complete removal of the IL from the fibers. These findings were also supported by elemental analysis, which also revealed the absence of any IL.

The orientation of the fibers was quantified by birefringence and XRD measurements. With the aid of the birefringence values $(\Delta n)$ the total orientation $\left(f_{\mathrm{t}}\right)$ was calculated, Table 3 . The high orientation values are caused by pre-oriented cellulose chains due to the stretching in the air gap.(Ingildeev et al. 2013; Michud et al. 2015c) The crystallite sizes $(t(\mathrm{hkl}))$ were calculated according to the deconvolution method using pseudo-Voigt functions for curve fitting, Fig. S9. The crystallite dimension of the (1-10) was 3.4 to $3.5 \mathrm{~nm}$ and 3.0 to $3.3 \mathrm{~nm}$ for fibers spun at $55^{\circ} \mathrm{C}$ and $65{ }^{\circ} \mathrm{C}$, respectively. Slightly smaller values were also obtained for the (110) and (020) reflexes at higher spinning temperature (Table 3). However, the crystallinity of all samples was between 72 and $81 \%$ and no significant temperature dependency was observed. 


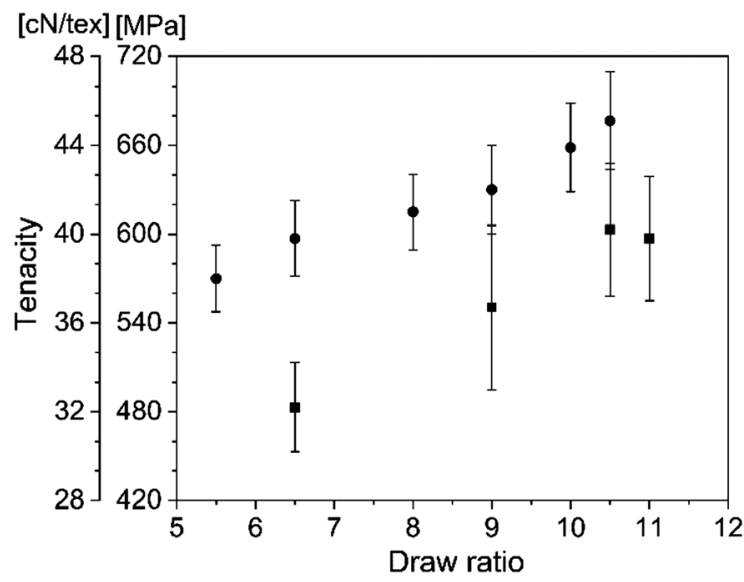

Fig. 4 Tenacity of dry-jet spun fibers spun at $55^{\circ} \mathrm{C}(\boldsymbol{\square})$ and $65{ }^{\circ} \mathrm{C}(\mathbf{)})$ as a function of the draw ratio

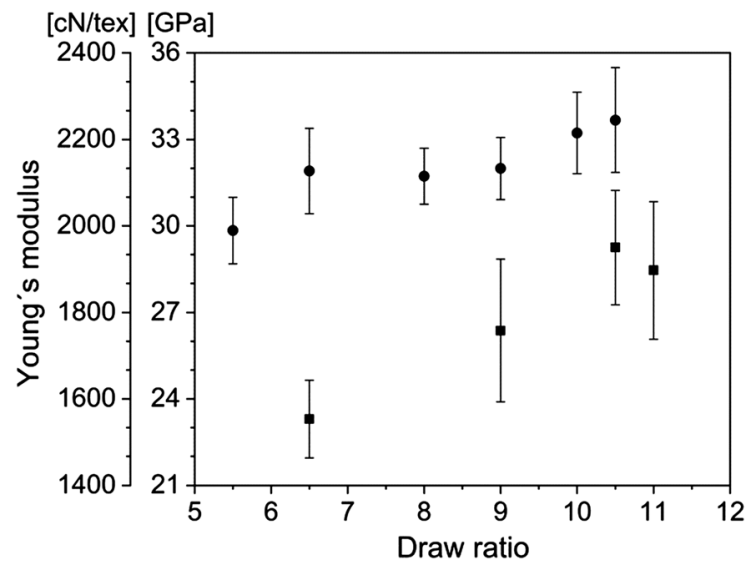

Fig. 5 Young's modulus of dry-jet spun fibers spun at $55^{\circ} \mathrm{C}$ (घ) and $65^{\circ} \mathrm{C}(\mathbf{)})$ as a function of the draw ratio

Fiber properties

The regenerated fibers showed a strong correlation between the draw ratio and the resulting properties. Furthermore, a correlation between the mechanical properties and the spinning temperature was found. As expected, the linear density (titer) of the fibers also depended significantly on the draw ratio. Thus, the titer decreased with increasing draw ratio of the spinning mass in the air gap, Fig. 3. Unsurprisingly, we found no correlation between the titer and the spinning temperature. Independent of the temperature, nearly the same fiber titer was obtained at a given draw ratio.

By contrast, both the tenacity and the Young's modulus of the dry-jet spun fibers are clearly affected by both the spinning temperature and the draw ratio (Figs. 4, 5). For both spinning trails the tenacity increased with increasing draw ratio. Therefore, the highest tenacity obtained at a draw ratio of 10.5 was $45.1 \pm 2.2 \mathrm{cN} /$ tex (65-6). Fibers spun at $55^{\circ} \mathrm{C}$ showed the same trend; tensile strength increased with increasing draw ratio. However, fibers spun at $55^{\circ} \mathrm{C}$ at a given draw ratio showed always a lower tensile strength compared to fibers spun at $65^{\circ} \mathrm{C}$. This trend could also be observed for the Young's modulus. The highest values of $2245 \pm 121 \mathrm{cN} /$ tex were achieved by spinning at $65^{\circ} \mathrm{C}$, while the maximum value of the spinning trial at $55^{\circ} \mathrm{C}$ was $1950 \pm 132$ $\mathrm{cN} / \mathrm{tex}$.

We attribute these findings to the lower orientation of the cellulose chains in the fibers prepared at $55^{\circ} \mathrm{C}$ compared to those spun at $65{ }^{\circ} \mathrm{C}$, the more since this is supported by the birefringence measurements, in which fibers spun at $65{ }^{\circ} \mathrm{C}$ showed a higher orientation. The higher orientation can be attributed to a higher mobility of the cellulose chains during the spinning process at higher temperature, which facilitates their orientation in the air gap. This in turn results in a better contact between the individual cellulose chains, which increases chain interactions and improves both tenacity and Young's modulus (Cook 1968). Finally, the elongation at break also depended on the draw ratio. Both temperature series, 55 and $65{ }^{\circ} \mathrm{C}$, showed values between 5 and $7 \%$, whereby the elongation decreased with increasing draw ratio.

Finally, we compared the mechanical properties of the dry-jet wet spun fiber (spun at $65{ }^{\circ} \mathrm{C}$, sample code 65-6) with a commercial tire cord fiber (Viscord 1840 CS3, Glanzstoff), Table 4. Both fiber types had tenacities around 44-45 cN/tex. Nonetheless, the obtained Young's modulus of the dry-jet wet spun fiber was twice as high as the one of the Viscord fiber. Also, a higher orientation factor of the dry-jet spun fiber was determined by birefringence measurements. This difference can be attributed to the different spinning processes. The IL fibers also showed a higher crystallinity $(75 \%)$ than commercial Viscord fibers (68\%). While Viscord fibers are produced by wet spinning, the process described here is based on air gap spinning. The air gap has a strong effect on the molecular orientation and mechanical properties (modulus of elasticity). A comparison of the stressstrain curves of the fibers is shown in Fig. S11 (S.I.). 
Table 4 Structural parameters and mechanical properties of dry-jet spun and commercial fibers (Viscord 1840 CS3, Glanzstoff)

\begin{tabular}{lll}
\hline Fiber type & Dry-jet spun (65-6) & Viscord (1840 CS3) \\
\hline $\mathrm{f}_{\mathrm{t}}$ & $0.79 \pm 0.02$ & $0.57 \pm 0.06$ \\
$\mathrm{Ic}(\%)$ & $75 \pm 4$ & $68 \pm 3$ \\
$(1-10)(\mathrm{nm})$ & 3.14 & 3.58 \\
$(110)(\mathrm{nm})$ & 3.41 & 3.62 \\
$(020)(\mathrm{nm})$ & 4.93 & 3.74 \\
Fineness (dtex) & 1.10 & 2.05 \\
Elongation at break (\%) & $5.0 \pm 0.8$ & $14.5 \pm 2.5$ \\
Tenacity (cN/tex) & $45 \pm 2$ & $44 \pm 4$ \\
Young's modulus (cN/tex) & $2250 \pm 120$ & $1150 \pm 80$ \\
\hline
\end{tabular}

However, the influence of the air gap on the fiber properties has been shown to pose some challenges. Thus, as a result of the higher orientation of air gap spun fibers, their elongation at break is significantly lower than the one of viscose fibers. It is well known that the elongation at break of regenerated fibers depend on the fiber forming process (Lenz et al. 1994). In fact, the orientation of the fibers significantly affects elongation as the orientation of the cellulose molecules in the fibers increases, while break elongation decreases. In order to improve the elongation at break, regulation of the air gap conditions (AGC), which has been shown to allow for an increased elongation at break (Guizani et al. 2020; Zhang et al. 2017b) can be envisaged.

\section{Conclusions}

Today, cellulose-based tire cord fibers are produced by the viscose process. The main disadvantage of this process is the high amount of toxic and environmentally problematic chemicals like carbon disulfide or zinc salts, which requires a complex and expensive purification of both waste water and emission gasses. In this study, we outlined a new cellulose tire cord fiber based on the IL-technology, which does not require any chemical pretreatment/conversion or chemical stabilization of the spinning solution to dissolve the cellulose. The fibers produced by the new air gap spinning process have a dense structure and smooth surface. The mechanical properties can be controlled by the draw ratio and the spinning temperature. Increasing the spinning temperature results in increased fiber strength and Young's modulus. The obtained mechanical properties significantly exceed those of commercial tire cord fibers. Thus, the tenacity values where similar (around $44 \mathrm{cN} /$ tex) while the Young's modulus was with $2245 \pm 121 \mathrm{cN} /$ tex twice as high.

Finally, spinning is not negatively influenced by an increasing concentrating of $\left[\mathrm{C}_{2} \mathrm{C}_{1} \mathrm{im}\right][\mathrm{Oc}]$ in the coagulation bath. Currently, we investigate the influence of recycled ILs on spinnability and fiber properties.

Acknowledgments The authors would like to thank Sabine Henzler and Ulrich Hageroth for performing SEM and birefringence measurements.

Funding Open Access funding enabled and organized by Projekt DEAL.

Open Access This article is licensed under a Creative Commons Attribution 4.0 International License, which permits use, sharing, adaptation, distribution and reproduction in any medium or format, as long as you give appropriate credit to the original author(s) and the source, provide a link to the Creative Commons licence, and indicate if changes were made. The images or other third party material in this article are included in the article's Creative Commons licence, unless indicated otherwise in a credit line to the material. If material is not included in the article's Creative Commons licence and your intended use is not permitted by statutory regulation or exceeds the permitted use, you will need to obtain permission directly from the copyright holder. To view a copy of this licence, visit http://creativecommons.org/licenses/by/4.0/.

\section{References}

Abels F, Cwik T, Beyer R, Hermanutz F (2017) Process for the preparation of polymer fibers from polymers dissolved in 
ionic liquids by means of an air gap spinning process. Germany Patent WO2017/137284AI.

Ahmad W, Ostonen A, Jakobsson K, Uusi-Kyyny P, Alopaeus V, Hyväkkö U, King AWT (2016) Feasibility of thermal separation in recycling of the distillable ionic liquid [DBNH][OAc] in cellulose fiber production. Chem Eng Res Des 114:287-298. https://doi.org/10.1016/j.cherd. 2016.08.032

Archwal WB, Narayan TV, Puaro UM (1967) Alkaline irontatrate comples solutions as solvents for cellulosic materials. Part I. Application to the determination of intrinsic viscosity. Tappi J 50:90A-93A

Asaadi S, Hummel M, Hellsten S, Harkasalmi T, Ma Y, Michud A, Sixta H (2016) Renewable high-performance fibers from the chemical recycling of cotton waste utilizing an ionic liquid. Chemsuschem 9:3250-3258. https://doi.org/ $10.1002 /$ cssc. 201600680

Asaadi S, Hummel M, Ahvenainen P, Gubitosi M, Olsson U, Sixta H (2018) Structural analysis of Ioncell-F fibres from birch wood. Carbohydr Polym 181:893-901. https://doi. org/10.1016/j.carbpol.2017.11.062

Bouchard J, Méthot M, Jordan B (2006) The effects of ionizing radiation on the cellulose of woodfree paper. Cellulose 13:601-610. https://doi.org/10.1007/s10570-005-9033-0

Bredereck K, Hermanutz F (2005) Man-made cellulosics. Rev Prog Color Relat Top 35:59-75. https://doi.org/10.1111/j. 1478-4408.2005.tb00160.x

Clough MT, Geyer K, Hunt PA, Son S, Vagt U, Welton T (2015) Ionic liquids: not always innocent solvents for cellulose. Green Chem 17:231-243. https://doi.org/10.1039/ c4gc01955e

Cook JG (1968) Handbook of textile fibres, 4th edn. Merrow Publishing Co. Ltd, Watford

Couling DJ, Bernot RJ, Docherty KM, Dixon JK, Maginn EJ (2006) Assessing the factors responsible for ionic liquid toxicity to aquatic organisms via quantitative structureproperty relationship modeling. Green Chem 8:82-90. https://doi.org/10.1039/b511333d

Driscoll M et al (2009) Electron beam irradiation of cellulose. Radiat Phys Chem 78:539-542. https://doi.org/10.1016/j. radphyschem.2009.03.080

Ebner G, Schiehser S, Potthast A, Rosenau T (2008) Side reaction of cellulose with common 1-alkyl-3-methylimidazolium-based ionic liquids. Tetrahedron Lett 49:7322-7324. https://doi.org/10.1016/j.tetlet.2008.10. 052

El Seoud OA, Kostag M, Jedvert K, Malek NI (2020) Cellulose regeneration and chemical recycling: closing the "Cellulose Gap" using environmentally benign solvents. Macromol Mater Eng:1900832. https://doi.org/10.1002/ mame. 201900832

Elsayed S et al (2020) Recycling of superbase-based ionic liquid solvents for the production of textile-grade regenerated cellulose fibers in the lyocell process. ACS Sustain Chem Eng 8:14217-14227. https://doi.org/10.1021/ acssuschemeng.0c05330

Emsley AM, Stevens GC (1994) Kinetics and mechanisms of the low-temperature degradation of cellulose. Cellulose 1:26-56. https://doi.org/10.1007/bf00818797

Fechter C, Fischer S, Reimann F, Brelid H, Heinze T (2020) Influence of pulp characteristics on the properties of alkali cellulose. Cellulose 27:7227-7241. https://doi.org/10. 1007/s10570-020-03151-4

Fink HP, Weigel P, Purz HJ, Ganster J (2001) Structure formation of regenerated cellulose materials from NMMOsolutions. Prog Polym Sci 26:1473-1524. https://doi.org/ 10.1016/S0079-6700(01)00025-9

Gahleitner M, Sobczak R (1989) Importance of the zero shear viscosity determination to the modelling of flow curves. Kunst-Ger Plast 79:1213-1216

Guizani C, Nieminen K, Rissanen M, Larkiala S, Hummel M, Sixta $H$ (2020) New insights into the air gap conditioning effects during the dry-jet wet spinning of an ionic liquidcellulose solution. Cellulose:4931-4948. https://doi.org/ 10.1007/s10570-020-03115-8

Haemmerle FM (2011) The cellulose gap (the future of cellulose fibers). Lenzinger Ber 89:12-21

Haslinger S, Hummel M, Anghelescu-Hakala A, Maattanen M, Sixta H (2019a) Upcycling of cotton polyester blended textile waste to new man-made cellulose fibers. Waste Manag 97:88-96. https://doi.org/10.1016/j.wasman.2019. 07.040

Haslinger S et al (2019b) Recycling of vat and reactive dyed textile waste to new colored man-made cellulose fibers. Green Chem 21:5598-5610. https://doi.org/10.1039/ c9gc02776a

Haslinger S, Ye Y, Rissanen M, Hummel M, Sixta H (2019c) Cellulose fibers for high-performance textiles functionalized with incorporated gold and silver nanoparticles. ACS Sustain Chem Eng 8:649-658. https://doi.org/10.1021/ acssuschemeng.9b06385

Hauru LKJ, Hummel M, Michud A, Sixta H (2014) Dry jet-wet spinning of strong cellulose filaments from ionic liquid solution. Cellulose 21:4471-4481. https://doi.org/10.1007/ s10570-014-0414-0

Henniges U, Okubayashi S, Rosenau T, Potthast A (2012) Irradiation of cellulosic pulps: understanding its impact on cellulose oxidation. Biomacromol 13:4171-4178. https:// doi.org/10.1021/bm3014457

Henniges U, Hasani M, Potthast A, Westman G, Rosenau T (2013) Electron beam irradiation of cellulosic materialsopportunities and limitations. Materials 6:1584-1598. https://doi.org/10.3390/ma6051584

Hermanutz F, Vocht MP, Panzier N, Buchmeiser MR (2018) Processing of cellulose using ionic liquids. Macromol Mater Eng:1800450. https://doi.org/10.1002/mame. 201800450

Hermanutz F, Vocht MP, Buchmeiser MR (2020) Development of new cellulosic fibers and composites using ionic liquid technology. In: Shiflett M (ed) Commercial applications of ionic liquids Green chemistry and sustainable technology, vol 1. Springer, Cham, pp 227-259. https://doi.org/10. 1007/978-3-030-35245-5_10

Hough WL et al (2007) The third evolution of ionic liquids: active pharmaceutical ingredients. New J Chem 31:1429-1436. https://doi.org/10.1039/b706677p

Hummel M et al. (2015) Ionic liquids for the production of manmade cellulosic fibers-opportunities and challenges. In: Cellulose chemistry and properties: fibers, nanocelluloses and advanced materials. Advances in polymer science. pp 133-168. https://doi.org/10.1007/12_2015_307 
Hwang Y, Park H-J, Potthast A, Jeong M-J (2020) Evaluation of cellulose paper degradation irradiated by an electron beam for conservation treatment. Cellulose. https://doi.org/10. 1007/s10570-020-03604-w

Imamura R, Ueno T, Murakami K (1972) Depolymerization of cellulose by electron beam irradiation. Bull Inst Chem Res Kyoto Univ 50:51-63

Ingildeev D, Effenberger F, Bredereck K, Hermanutz F (2013) Comparison of direct solvents for regenerated cellulosic fibers via the lyocell process and by means of ionic liquids. J Appl Polym Sci 128:4141-4150. https://doi.org/10.1002/ app. 38470

Isik M, Sardon H, Mecerreyes D (2014) Ionic liquids and cellulose: dissolution, chemical modification and preparation of new cellulosic materials. Int $J$ Molec Sci 15:11922-11940. https://doi.org/10.3390/ijms 150711922

Jiang G et al (2012) Analysis of regenerated cellulose fibers with ionic liquids as a solvent as spinning speed is increased. Cellulose 19:1075-1083. https://doi.org/10.1007/s10570012-9716-2

King AWT, Parviainen A, Karhunen P, Matikainen J, Hauru LKJ, Sixta H, Kilpeläinen I (2012) Relative and inherent reactivities of imidazolium-based ionic liquids: the implications for lignocellulose processing applications. RSC Adv 2:8020-8026. https://doi.org/10.1039/c2ra21287k

Kosan B, Michels C, Meister F (2007) Dissolution and forming of cellulose with ionic liquids. Cellulose 15:59-66. https:// doi.org/10.1007/s10570-007-9160-X

Kosan B, Schwikal K, Meister F (2012) Effects of pre-treatment and dissolution conditions for improved solution and processing properties of cellulose in ionic liquids. Lenzinger Ber 90:76-84

Lang O, Wisniewski T, Lutz M (2013) Short path distillation of ionic liquids. Germany Patent WO 2013/171060.

Lenz J, Schurz J, Wrentschur E (1992) Comparative characterization of solvent spun cellulose and high wet modulus viscose fibres by their long periods. Acta Polym 43:307-312. https://doi.org/10.1002/actp.1992.010430603

Lenz J, Schurz J, Wrentschur E (1993) Properties and structure of solvent-spun and viscose-type fibres in the swollen state. Colloid Polym Sci 271:460-468. https://doi.org/10.1007/ BF00657390

Lenz J, Schurz J, Wrentschur E (1994) On the elongation mechanism of regenerated cellulose fibres. Holzforschung 48:72-76. https://doi.org/10.1515/hfsg.1994.48.s1.72

Loubinoux D, Chaunis S (1987) An experimental approach to spinning new cellulose fibers with n-methylmorpholineoxide as a solvent text. Res J 57:61-65. https://doi.org/10. $1177 / 004051758705700201$

Ma Y, Hummel M, Määttänen M, Särkilahti A, Harlin A, Sixta $\mathrm{H}$ (2016) Upcycling of waste paper and cardboard to textiles. Green Chem 18:858-866. https://doi.org/10.1039/ c5gc01679g

McLaren KG (1978) Degradation of cellulose in irradiated wood and purified celluloses. Int $\mathrm{J}$ Appl Radiat Isot 29:631-635. 708x(78)90098-4 https://doi.org/10.1016/0020-

Michud A, Hummel M, Haward S, Sixta H (2015a) Monitoring of cellulose depolymerization in 1-ethyl-3-methylimidazolium acetate by shear and elongational rheology.
Carbohydr Polym 117:355-363. https://doi.org/10.1016/j. carbpol.2014.09.075

Michud A, Hummel M, Sixta H (2015b) Influence of molar mass distribution on the final properties of fibers regenerated from cellulose dissolved in ionic liquid by dry-jet wet spinning. Polymer 75:1-9. https://doi.org/10.1016/j. polymer.2015.08.017

Michud A et al (2015c) Ioncell-F: ionic liquid-based cellulosic textile fibers as an alternative to viscose and lyocell text. Res J 86:543-552. https://doi.org/10.1177/ 0040517515591774

Michud A, Hummel M, Sixta H (2016) Influence of process parameters on the structure formation of man-made cellulosic fibers from ionic liquid solution. J Appl Polym Sci 133:43718. https://doi.org/10.1002/app.43718

Mittal N et al (2018) Multiscale control of nanocellulose assembly: transferring remarkable nanoscale fibril mechanics to macroscale fibers. ACS Nano 12:6378-6388. https://doi.org/10.1021/acsnano.8b01084

Mittal N, Benselfelt T, Ansari F, Gordeyeva K, Roth SV, Wågberg L, Söderberg LD (2019) Ion-specific assembly of strong, tough, and stiff biofibers. Angew Chem Int Ed 131:18735-18742. https://doi.org/10.1002/ange. 201910603

Nakamura Y, Ogiwara Y, Phillips GO (1985) Free radical formation and degradation of cellulose by ionizing radiations. Polym Photochem 6:135-159. https://doi.org/10.1016/ 0144-2880(85)90020-x

Olsson C, Westman G (2013) Wet spinning of cellulose from ionic liquid solutions-viscometry and mechanical performance. J App Polym Sci 127:4542-4548. https://doi.org/ 10.1002/app.38064

Olsson C, Hedlund A, Idström A, Westman G (2014) Effect of methylimidazole on cellulose/ionic liquid solutions and regenerated material therefrom. J Mater Sci 49:3423-3433. https://doi.org/10.1007/s10853-014-8052-3

Osmanbegovic N, Yuan L, Lorenz H, Louhi-Kultanen M (2020) Freeze concentration of aqueous [DBNH][OAc] ionic liquid solution. Crystals. https://doi.org/10.3390/ cryst10030147

Ostadjoo S, Berton P, Shamshina JL, Rogers RD (2018) Scaling-up ionic liquid-based technologies: How much do we care about their toxicity? Prima facie information on 1-ethyl-3-methylimidazolium acetate. Toxicol Sci 161:249-265. https://doi.org/10.1093/toxsci/kfx172

Ostonen A et al (2016) Experimental and theoretical thermodynamic study of distillable ionic liquid 1,5-Diazabicyclo[4.3.0]non-5-enium acetate. Ind Eng Chem Res 55:10445-10454. https://doi.org/10.1021/acs.iecr. 6b02417

Parviainen A et al (2013) Predicting cellulose solvating capabilities of acid-base conjugate ionic liquids. Chemsuschem 6:2161-2169. https://doi.org/10.1002/cssc.201300143

Parviainen A et al (2015) Sustainability of cellulose dissolution and regeneration in 1,5-diazabicyclo[4.3.0]non-5-enium acetate: a batch simulation of the IONCELL-F process. RSC Adv 5:69728-69737. https://doi.org/10.1039/ C5RA12386K

Rongpipi S, Ye D, Gomez ED, Gomez EW (2018) Progress and opportunities in the characterization of cellulose-an important regulator of cell wall growth and mechanics. 
Front Plant Sci 9:1894. https://doi.org/10.3389/fpls.2018. 01894

Rosenau T, Potthast A, Adorjan I, Hofinger A, Sixta H, Firgo H, Kosma P (2002) Cellulose solutions in N-methylmorpholine-N-oxide (NMMO) - degeradtion processes and stabilizers. Cellulose 9:283-291. https://doi.org/10.1023/A: 1021127423041

Ruokonen SK et al (2016) Effect of Ionic liquids on zebrafish (danio rerio) viability, behavior, and histology; correlation between toxicity and ionic liquid aggregation. Environ Sci Technol 50:7116-7125. https://doi.org/10.1021/acs.est. $5 \mathrm{~b} 06107$

Sayyed AJ, Deshmukh NA, Pinjari DV (2019) A critical review of manufacturing processes used in regenerated cellulosic fibres: viscose, cellulose acetate, cuprammonium, $\mathrm{LiCl} /$ DMAc, ionic liquids, and NMMO based lyocell. Cellulose 26:2913-2940. https://doi.org/10.1007/s10570-01902318-y

Scherrer P (1918) Bestimmung der inneren Struktur und der Größe von Kolloidteilchen mittels Röntgenstrahlen. In: Kolloidchemie Ein Lehrbuch Gött Nachr, pp 98-100

Schneck TK, Müller A, Hermanutz F, Buchmeiser MR (2019) Preparation of $\mathrm{C} / \mathrm{C}-\mathrm{SiC}$ Composites from all-cellulose precursors. Macromol Mater Eng. https://doi.org/10.1002/ mame. 201800763

Schuster KC, Rohrer C, Eichinger D, Schmidtbauer J, Aldred P, Firgo H (2004) Environmentally friendly lyocell fibers. In: Wallenberger FT, Weston NE (eds) Natural fibers, plastics and composites. Springer, Boston, MA, pp 123-146. https://doi.org/10.1007/978-1-4419-9050-1_9

Seo YB, Lee MW, Park DH, Park HJ (2013) Use of a Lowenergy electron beam for degree of polymerization control of cotton linter. Ind Eng Chem Res 52:692-695. https://doi. org/10.1021/ie300521w

Shearer AB (1925) Artificial silk; a review of british progress. The industrial development of viscose. J Text Inst 16:P146-P154. 19447012508665494

https://doi.org/10.1080/

Sixta H et al (2015) Ioncell-F: a high-strength regenerated cellulose fibre. Nord Pulp Pap Res J 30:43-57. https://doi.org/ 10.3183/npprj-2015-30-01-p043-057

Spörl JM, Batti F, Vocht MP, Raab R, Müller A, Hermanutz F, Buchmeiser MR (2017a) Ionic liquid approach toward manufacture and full recycling of all-cellulose composites. Macromol Mater Eng 303:1700335. https://doi.org/10. 1002/mame.201700335

Spörl JM, Beyer R, Abels F, Cwik T, Müller A, Hermanutz F, Buchmeiser MR (2017b) Cellulose-derived carbon fibers with improved carbon yield and mechanical properties. Macromol Mater Eng 302:1700195. https://doi.org/10. 1002/mame.201700195

Stepanik TM, Ewing DE, Whitehouse R (2000) Electron treatment of wood pulp for the viscose process. Radiat Phys Chem 57:377-379. https://doi.org/10.1016/s0969806x(99)00408-9

Sun N, Rodríguez H, Rahman M, Rogers RD (2011) Where are ionic liquid strategies most suited in the pursuit of chemicals and energy from lignocellulosic biomass? Chem Commun 47:1405-1421. https://doi.org/10.1039/ C0CC03990J
Swatloski RP, Spear SK, Holbrey JD, Rogers RD (2002) Dissolution of cellulose [correction of cellose] with ionic liquids. J Am Chem Soc 124:4974-4975. https://doi.org/10. 1021/ja025790m

The Fibre Year 2019: World Survey onTextiles \& Nonwovens (2019), 19th edn. Fiber Year GmbH, Speicher

Vehviläinen M, Kamppuri T, Grönqvist S, Rissanen M, Maloney T, Honkanen M, Nousiainen P (2015) Dissolution of enzyme-treated cellulose using freezing-thawing method and the properties of fibres regenerated from the solution. Cellulose 22:1653-1674. https://doi.org/10.1007/s10570015-0632-0

Vigliani EC (1954) Carbon disulphide poisoning in viscose rayon factories. Br J Ind Med 11:235-244. https://doi.org/ 10.1136/oem.11.4.235

Wanasekara ND, Michud A, Zhu C, Rahatekar S, Sixtat H, Eichhorn SJ (2016) Deformation mechanisms in ionic liquid spun cellulose fibers. Polym 99:222-230. https://doi. org/10.1016/j.polymer.2016.07.007

Wang H, Gurau G, Rogers RD (2012) Ionic liquid processing of cellulose. Chem Soc Rev 41:1519-1537. https://doi.org/ $10.1039 / \mathrm{c} 2 \mathrm{cs} 15311 \mathrm{~d}$

Wooding CR (1995) The development of advanced cellulosic fibres. Int J Biol Macromol 17:305-309. https://doi.org/10. 1016/0141-8130(96)81836-8

Yamane C, Mori M, Saito M, Okajima K (1996) Structures and mechanical properties of cellulose filament spun from cellulose/aqueous $\mathrm{NaOH}$ solution system. Polym J 28:1039-1047. https://doi.org/10.1295/polymj.28.1039

Zadorecki P, Karnerfors H, Lindenfors S (1986) Cellulose fibers as reinforcement in composites: determination of the stiffness of cellulose fibers. Compos Sci Technol 27:291-303. 3538(86)90072-2

Zhang J, Wu J, Yu J, Zhang X, He J, Zhang J (2017a) Application of ionic liquids for dissolving cellulose and fabricating cellulose-based materials: state of the art and future trends. Mater Chem Front 1:1273-1290. https://doi.org/10. 1039/c6qm00348f

Zhang J, Yamagishi N, Tominaga K, Gotoh Y (2017b) Highstrength regenerated cellulose fibers spun from 1-butyl-3methylimidazolium chloride solutions. J App Polym Sci 134:45551. https://doi.org/10.1002/app.45551

Zhang S et al (2018) Regenerated cellulose by the lyocell process, a brief review of the process and properties. Bioresources 13:1-16. https://doi.org/10.15376/biores.13.2

Zhang J, Yamagishi N, Gotoh Y, Potthast A, Rosenau T (2019) High performance cellulose fibers regenerated from 1-butyl-3-methylimidazolium chloride solution: effects of viscosity and molecular weight. J App Polym Sci 137:48681. https://doi.org/10.1002/app.48681

Zhang J, Tominaga K, Yamagishi N, Gotoh Y (2020) Comparison of regenerated cellulose fibers spun from ionic liquid solutions with lyocell fiber. J Fiber Sci Technol 76:257-266. https://doi.org/10.2115/fiberst.2020-0029

Publisher's Note Springer Nature remains neutral with regard to jurisdictional claims in published maps and institutional affiliations. 